EPiC Series in Engineering
Volume 3, 2018, Pages 1495-1504
HIC 2018. 13th International
Conference on Hydroinformatics

\title{
High Resolution Urban Flood Modelling: A Case Study of Cork City, Ireland
}

\author{
Stephen Nash ${ }^{1,2,3^{*}}$, Joanne Comer ${ }^{4}$, Agnieszka Olbert ${ }^{1,2,3}$ and Michael \\ Hartnett ${ }^{1,2,3}$ \\ ${ }^{1}$ College of Engineering \& Informatics, National University of Ireland Galway, Ireland \\ ${ }^{2}$ Ryan Institute for Environmental, Marine and Energy Research, NUI Galway, Ireland \\ ${ }^{3}$ SFI Centre for Marine \& Renewable Energy Ireland (MaREI) \\ ${ }^{4}$ Office of Public Works, Galway, Ireland \\ stephen.nash@nuigalway.ie
}

\begin{abstract}
Flooding of coastal areas can be caused by a number of contributing factors: high river flows, high tides, storm surges or a combination thereof. This paper presents results of a numerical modelling investigation of the role of river flow in flooding of Cork City. The Cork City urban flood model was developed by dynamically linking a storm surge model of the northeast Atlantic with the multi-scale nested flood model, MSN_Flood, which uses nesting to telescope down from $90 \mathrm{~m}$ resolution in Cork Harbour to $2 \mathrm{~m}$ resolution in the city streets. LiDAR data was used to create the urban flood plain. The model is used to hindcast the 2009 major flood event and is shown to accurately recreate the flood levels and extents. The model is then used to investigate the contributions of river flows to flooding in the city by simulating a range of peak flow scenarios combined with spring and neap tidal conditions. It is shown that flooding is relatively minor for peak flows less than $300 \mathrm{~m}^{3} / \mathrm{s}$, while peak flows in excess of 500 $\mathrm{m}^{3} / \mathrm{s}$ result in extensive flooding of the city centre regardless of tidal condition.
\end{abstract}

\section{Introduction}

Globally, over 1.2 billion people live within $100 \mathrm{~km}$ of the coast in areas where the land height is less than $100 \mathrm{~m}$ above sea level (Small \& Nichols, 2003). These coastal zones are subject to coastal flooding, resulting in economic and social impacts including loss of life, damage to property and disruption of essential services. The large global coastal population and the recent global warming impacts of more frequent and intense rainfall events and rising sea levels means there is a critical need for accurate flood models to aid management and forecasting.

\footnotetext{
${ }^{*}$ Corresponding author
} 
The modelling of coastal flooding is a multi-scale problem that requires accurate solution at various scales ranging from coastal sea or estuary scale down to relatively narrow river channels and the dense street network of the inundated urban area. With the recent improvements in computing power and increasing availability of high resolution altimetry data (such as LiDAR), considerable developments have been made in the area of high resolution urban flood modelling. The complexity of hydraulic models varies greatly from simple 1D models (Mark et al., 2004) through 1D-2D linked models (Fewtrell et al., 2011) to advanced mass and momentum conserving 2D (Hunter et al., 2008) and 3D models (Yang et al., 2012). Hunter et al. (2008) provide a useful benchmarking of a number of 2D hydraulic models for urban flood modelling including the models TUFLOW, DIVAST, TRENT, JFLOW and LISFLOOD-FP.

In this research, a new urban flood modelling system involving multi-scale nesting is applied. The 2D depth-averaged, finite difference, multi-scale nested model (MSN) developed by Nash and Hartnett (2010) was adapted for flooding (MSN_Flood). An advantage of MSN_Flood is its method of treatment of flooding and drying on a nested boundary which allows complex evolutions of the boundaries; this is particularly suited to modelling the discontinuous propagation of flood waters across a boundary. The research presents the application of MSN_Flood to urban flooding in Cork City on the south coast of Ireland, a city that is regularly subject to combined fluvial and coastal flood events. The city is dominated by the River Lee (Figure 1) which flows east-to-west, splitting into two channels on the western side of the city before merging again to a single channel on the eastern side and flowing into Cork Harbour. MSN_Flood was applied to Cork City to hind-cast the major coastal flood event of 2009 and to investigate flooding mechanisms, in particular the fluvial contribution to flooding in the city.

\section{Coastal and Fluvial Flooding in Ireland}

Due to Ireland's exposure to meteorological and oceanic conditions present in the northeast Atlantic Ocean, Irish coastal towns and cities are often subject to flooding. This flooding is generally caused by three phenomena: high astronomical tides, storm surges and high river flows, or a combination of thereof (OPW, 2003). Although, the majority of flood events are primarily fluvial in nature (e.g. August 1986, November 2002, November 2009, June 2012), in the past 15 years there have been several severe coastal (tidal and surge) floods (e.g. February 2002, October 2004, June 2012 and January 2014). The most devastating flood in recent years was the November 2009 flood, where a combination of high tides, moderate surge and an extensive period of intense rainfall caused widespread coastal and inland flooding, including the extensive inundation of Cork City. Here, the fluvial mechanism was the primary flood controlling process while the high tides and surge acted to exacerbate the flooding (Olbert et al., 2015). The combination of fluvial and coastal flood mechanisms makes Cork City (Figure 1) a suitable case study for the research.

A brief description of the physical processes controlling flooding in Cork City is now given. Water levels in the River Lee estuary, on which Cork city is located, are dominated by sea water levels in Cork Harbour and upstream river flows discharging to it. Tidal motion in Cork Harbour is primarily driven by the M2 and S2 semidiurnal constituents of amplitude $1.41 \mathrm{~m}$ and $0.44 \mathrm{~m}$ (Cobh station), respectively. Direct connectivity to the northeast Atlantic Ocean affects frequency and severity of surges in Cork Harbour, which tend to vary seasonally and inter-annually depending upon climate modes such as the North Atlantic Oscillation. Surges propagate through Cork Harbour to the River Lee upstream, and when coinciding with spring high tides they can result in flooding of lowlying areas of the city. The River Lee which rises in the Shehy Mountains and flows into Cork Harbour drains a catchment area of approximately $2,000 \mathrm{~km} 2$. Two hydroelectric dams partly control the flow and are capable of dealing with floods up to an annual exceedence probability of $0.01 \%$. 
Downstream of the dams, the Rivers Bride and Shournagh flow into the River Lee. The median annual flows in the River Lee at river gauge station 19012 just upstream of Cork City is $185 \mathrm{~m}^{3} / \mathrm{s}$. By comparison, during the flood of 2009 , the flow in the river exceeded $550 \mathrm{~m}^{3} / \mathrm{s}$.

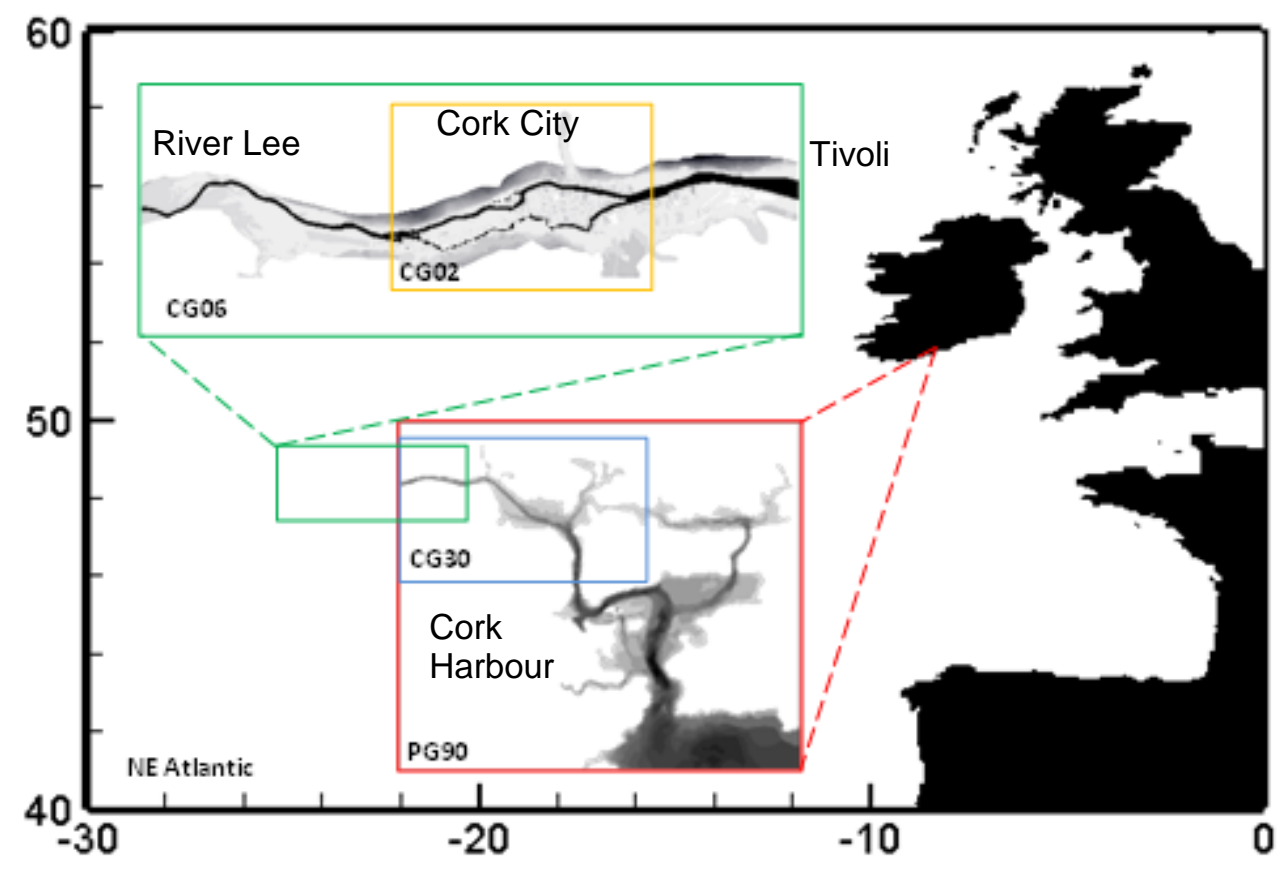

Figure 1: Nested grid configuration for Cork City application $(\mathrm{PG}=$ parent grid, $\mathrm{CG}=$ child grid $)$

\section{Methodology}

The urban flood model used in the research was MSN_Flood which was developed at National University of Ireland Galway. It is a 2D, depth-averaged, finite difference, coastal hydrodynamic model that simultaneously captures the combined effects of tidal variations, storm surges and river flows and can therefore be used to simulate coastal flooding in both urban and rural areas. In the model, urban infrastructures (roads, buildings, etc.) are combined with sea/river bed terrain models so that the flow of flood water from river/sea into complex urban environments can be accurately modelled. This is facilitated by unique nesting algorithms (see Nash and Hartnett $(2010,2014)$ for details) which allow flooding and drying of the nested boundaries so that their extents can evolve over time. Additional details of the MSN_Flood model are provided in Comer et al. (2017).

In the Cork City application, the model setup involved a cascade of 4 nested grids (Figure 1) where the spatial resolution varied from $90 \mathrm{~m}$ in the outer waters of Cork Harbour, through $30 \mathrm{~m}$ in the inner waters of the harbour, $6 \mathrm{~m}$ in the River Lee estuary and $2 \mathrm{~m}$ in the streets of Cork City. The Cork City MSN_Flood model is linked with a 3D ocean model of the northeast Atlantic developed using the Princeton Oceanographic Model (POM) which provides surge levels at the open sea boundary of the $90 \mathrm{~m}$ grid (PG90 in Figure 1).

The bathymetric model for the Cork study was developed using high resolution LiDAR data provided by the Office of Public Works (OPW). A resolution of $2 \mathrm{~m}$ was provided in both the digital 
surface model which included buildings and the digital terrain model which represented ground surface only (excluding buildings, etc). These data were combined and interpolated onto $6 \mathrm{~m}$ and $2 \mathrm{~m}$ regular Cartesian grids for the area of interest to produce the 'floodplain' topography. The channel of the River Lee was included in the model using cross sectional survey data also provided by the OPW from an extensive survey of the rivers in the River Lee catchment in 2008. Admiralty Chart data were used to develop the remainder of the bathymetric model of Cork Harbour.

The model was validated against survey data collected by OPW during and after the 2009 flood event. OPW measured maximum water levels at a number of locations along the river channel and in the city streets. They also produced a map of the maximum flood extents based on these measurements and other visual observations.

\section{Model Results}

Model accuracy was assessed by hind-casting the major November 2009 flood and comparing the flood levels and extents with measured data. The model was then used to investigate the contribution of the River Lee to flooding in the city through ensemble simulation of different flow scenarios.

\subsection{Hind-cast of November 2009 Flood}

The model was calibrated for the November 2009 flooding event. Boundary conditions at the time of flooding were extracted from river gauge station 19011 and the tide gauge at Tivoli (Figure 1) which were both operating on the day of the flooding (Figure 2). The roughness coefficients of the channel bed and floodplains were used as the calibrating parameters. Roughness varies across the model domain from the upstream section of the floodplain which is mostly fields, downstream to the city containing the urban environment. Flood levels computed by the model were compared with maximum water levels recorded by OPW immediately after the flood event (Figure 3a). The model shows very good agreement with observations (Figure 3b) with RMSE of $0.26 \mathrm{~m}$ and R2 of 0.97 . Figure 4 compares flood extents from the model hind-cast with observed flood extents compiled by OPW. Qualitatively, there is a very good agreement between the modelled and observed extents. Unfortunately the data used to produce the OPW extents map was not available and so a more quantitative statistical comparison of the datasets was not possible. More extensive details of the model validation for the 2009 Cork city flood are presented in Olbert et al. (2017).
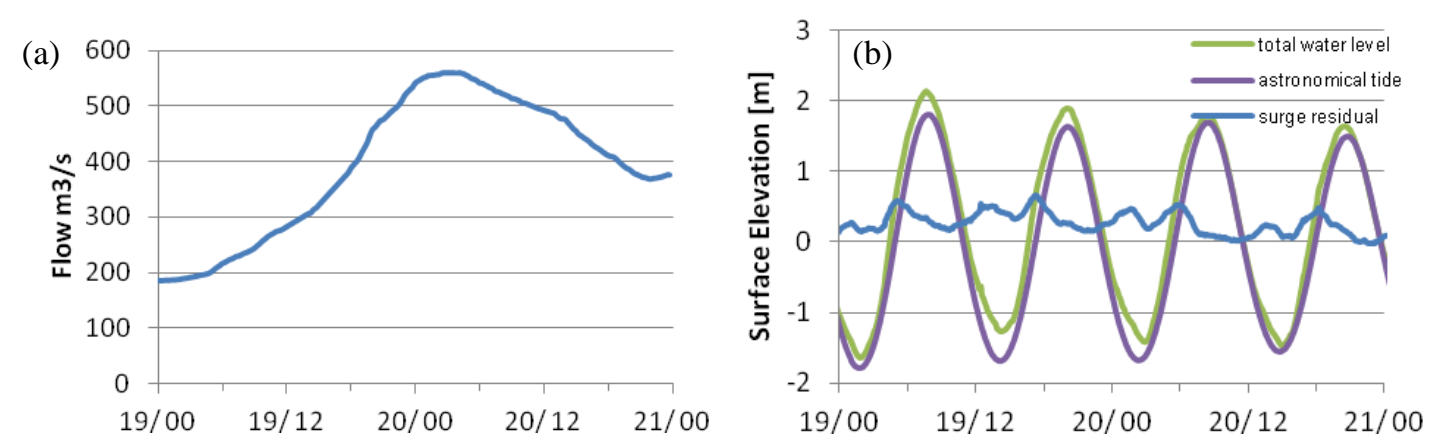

Figure 2: (a) River Lee flows at station 19011 and (b) tide levels at Tivoli, 19-20th Nov. 2009. 

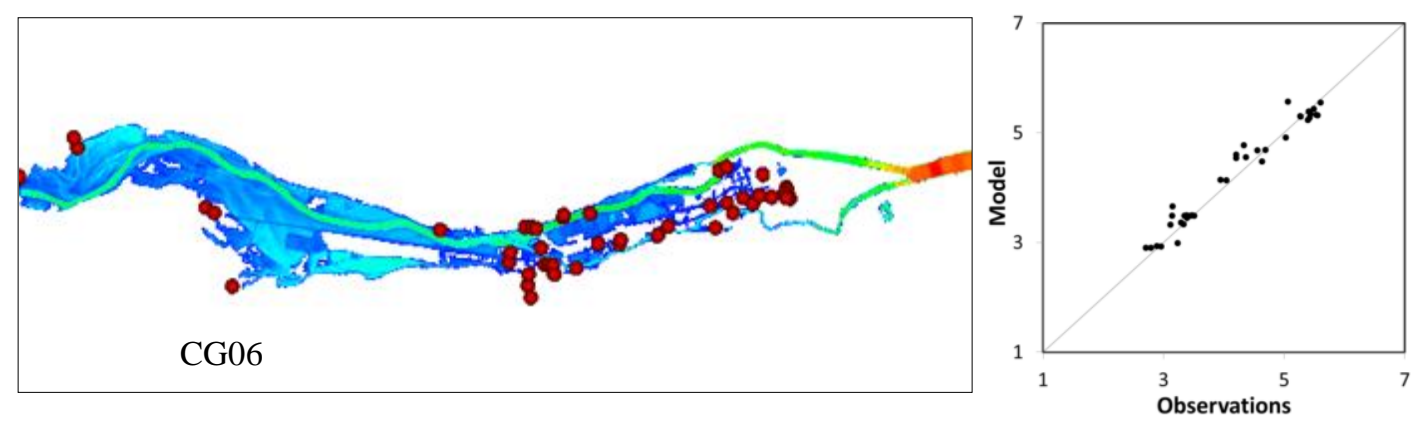

Figure 3: Locations of observed maximum water levels during the 2009 flood event
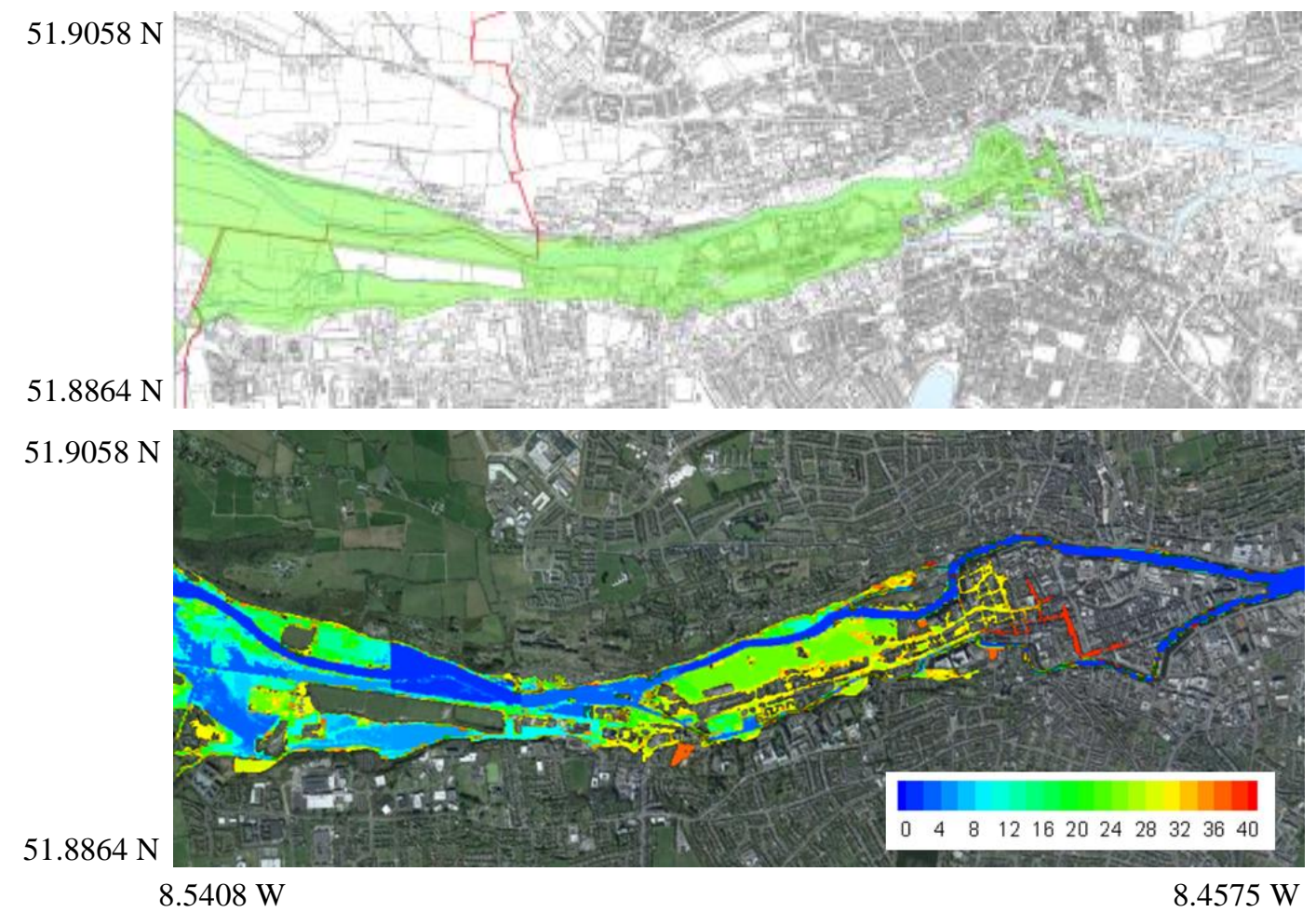

Figure 4: Maximum flood extents determined from OPW ground survey data (top) and the MSN_Flood model simulation (bottom).

The unique treatment of nested boundaries in MSN_Flood (see Nash and Hartnett $(2010,2014)$ and Comer et al. (2017)) allows the development of a non-continuous boundary with time, where segments of the boundary may be wet while others remain dry. The nested boundaries are formulated using a ghost-cell approach which ensures conservation of mass and momentum. Dirichlet conditions are used with specification of both surface elevation and $\mathrm{x}$ - and $\mathrm{y}$-velocity components. Parent grid boundary data are linearly interpolated in both time and space to the child grid resolution. The capability of boundary evolution is particularly suited to the modelling of urban floodplains where the river channel will initially mark the boundary extents but during flooding other separate sections of 
the boundary (e.g. city streets) may become wetted. Furthermore, depending on the flood water flow paths, the water levels along the separate sections of the boundary may differ in elevation. Figure 5 demonstrates the evolution of the western nested boundary of the highest resolution CG02 domain by showing variations in water levels along the boundary at different times during the flood event. It can be seen that the river channel is the only portion of the boundary that is initially wet but that other sections of the boundary later become wetted. It can also be seen that the water levels in the 'side channel' are higher than the water levels in the 'main channel' at the corresponding times. This difference in water level is due to the flood waters upstream of the boundary having to split to flow around an elevated strip of rural land.

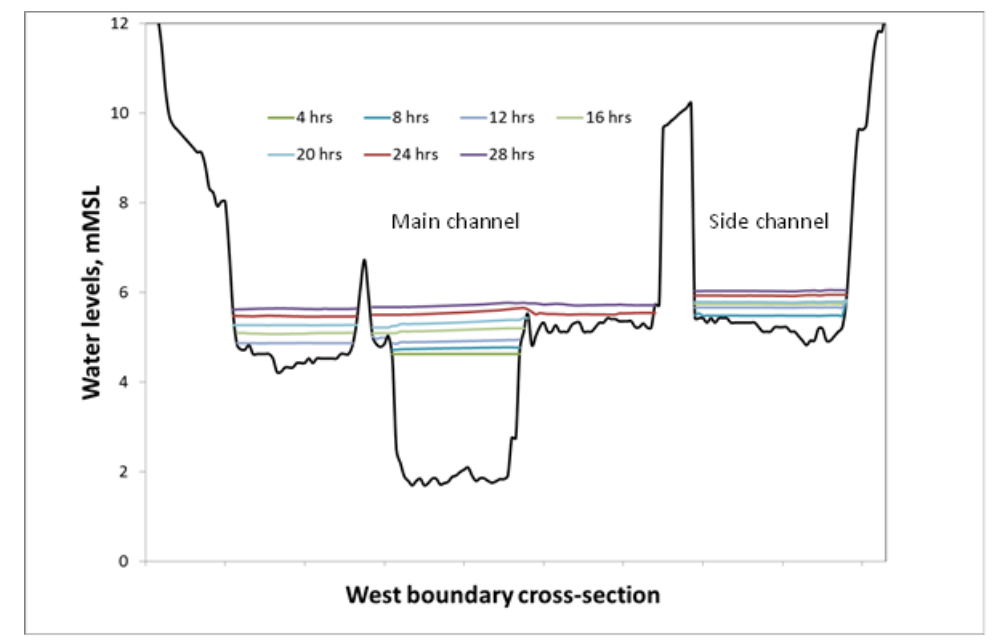

Figure 5: Cross section through western boundary of CG02 domain (see Figure 1) showing the temporal change in water levels along the nested boundary during the course of the flood.

\subsection{Role of Fluvial Flooding}

The effect of flow from the River Lee on flood extents in Cork city was examined by running an ensemble of simulations with different river flows and two sets of tidal conditions representing neap and spring tides of $1.0 \mathrm{~m}$ and $1.8 \mathrm{~m}$ amplitudes, respectively. Seven river flows in total were simulated with the same minimum flow but different peak flows. The shape of the flow curves replicated the temporal distribution of the Lee discharges during the November 2009 event (see Figure 2a). The minimum flow was taken as the River Lee's average annual flow of $40 \mathrm{~m}^{3} / \mathrm{s}$ while the peak flows were varied from $100-700 \mathrm{~m}^{3} / \mathrm{s}$ at $100 \mathrm{~m}^{3} / \mathrm{s}$ intervals. In all cases, the flow rate increased gradually from base flow to reach its peak approximately 26 hours later.

Figure 6 shows the temporal progress of Cork City inundation for each of the simulated river flows in terms of the area of inundated floodplain. It can be seen that there is a non-linear relationship between river flow rates and the extents of inundation. This is confirmed by Figure 7 which plots the maximum inundated area against the causative peak flow rate. The best-fit trendlines are non-linear. At the time of maximum inundation, a doubling of the peak flow from 100 to $200 \mathrm{~m}^{3} / \mathrm{s}$ results in a 10 fold growth in inundated area while a further doubling of the peak flow from 200 to $400 \mathrm{~m}^{3} / \mathrm{s}$ only affects a 5-fold increase in inundated area. Comparing results for spring and neap tides, it is clear that spring tides exacerbate the effect of flooding; the maximum inundated area is approximately 5\% larger on a spring tide than on a neap tide and the timing of maximum flooding is delayed. These differences are confined to the most downstream section of the city. 


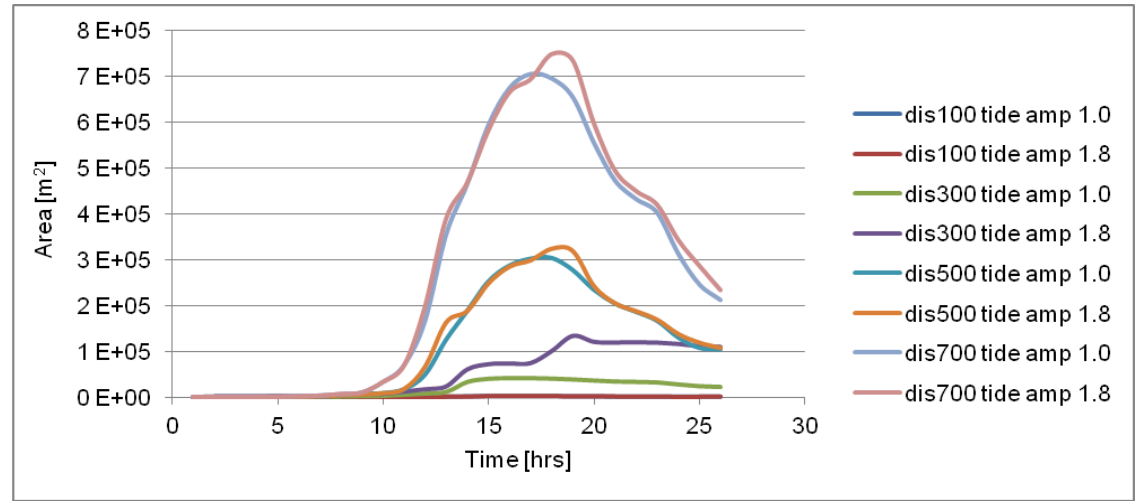

Figure 6: Timeseries of variation in area of inundation of urban flooding for different combinations of peak river flows with spring and neap tides (dis = peak river discharge, tide amp = tidal amplitude).

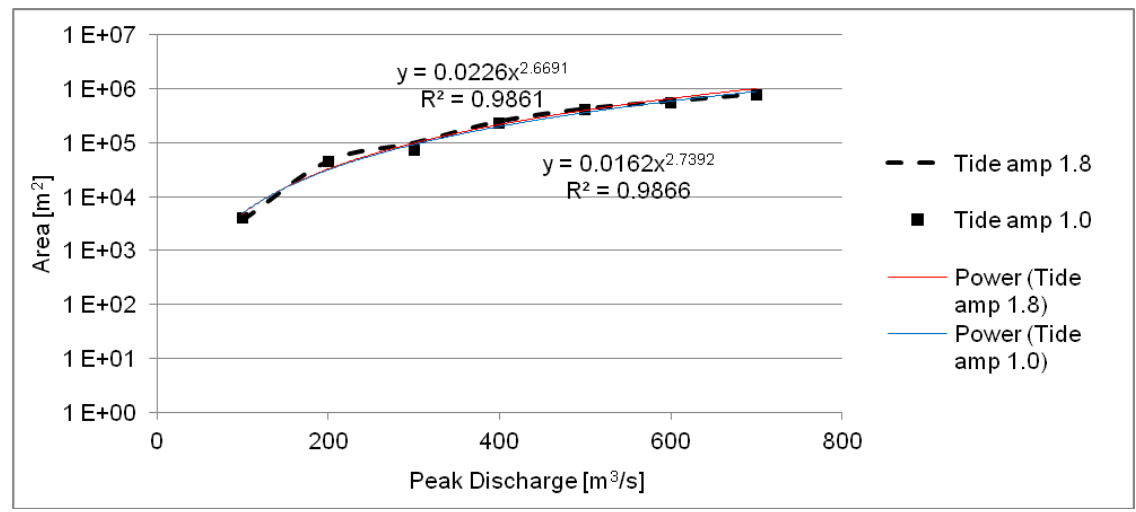

Figure 7: Maximum area of inundation of urban flooding versus the causative peak flow rate shown for both the spring and neap tidal conditions (note logarithmic scale for inundated area).

A fuller understanding of fluvial flooding mechanics in the city can be provided by investigating the spatial evolution of the flooding. Figure 8 shows contour maps of river flood wave evolution through the city floodplains for three selected river flow scenarios $\left(300,500\right.$ and $\left.700 \mathrm{~m}^{3} / \mathrm{s}\right)$ on a neap tide. The maps plot the extents of the inundated area at two-hourly intervals during the course of the flood event. It can be seen that once the capacity of the river is exceeded, the flow starts to spill into the floodplains at numerous locations along the river bank. As expected from Figure 6, the scenario with peak flow of $300 \mathrm{~m}^{3} / \mathrm{s}$ causes relatively minor flooding of low-lying locations in the upstream section of the river (Figure 8a). For the flows of 500 and $700 \mathrm{~m}^{3} / \mathrm{s}$, flooding progresses much more rapidly through the city and reaches its maximum extents approximately 10 hours after the first ingress of floodwaters. During this period, the flood wave propagates eastward from the upstream rural floodplains into the narrow city streets of the western part of the city between the north and south channels of the river. The contribution from the north channel is significantly greater than that from the south channel. The flow through the floodplains is highly unsteady as it moves to follow the terrain and avoid obstacles. Water moves along preferential flow paths in a primarily west-east direction through recreational fields along the river and major streets before reaching a ponding area in the low-lying streets of the eastern part of the city. While the eastern city centre is only marginally 
flooded for the $500 \mathrm{~m}^{3} / \mathrm{s}$ peak flow rate (Figure $8 \mathrm{~b}$ ), the $700 \mathrm{~m}^{3} / \mathrm{s}$ peak flow scenario results in a significant portion of the city centre becoming submerged (Figure 8c).
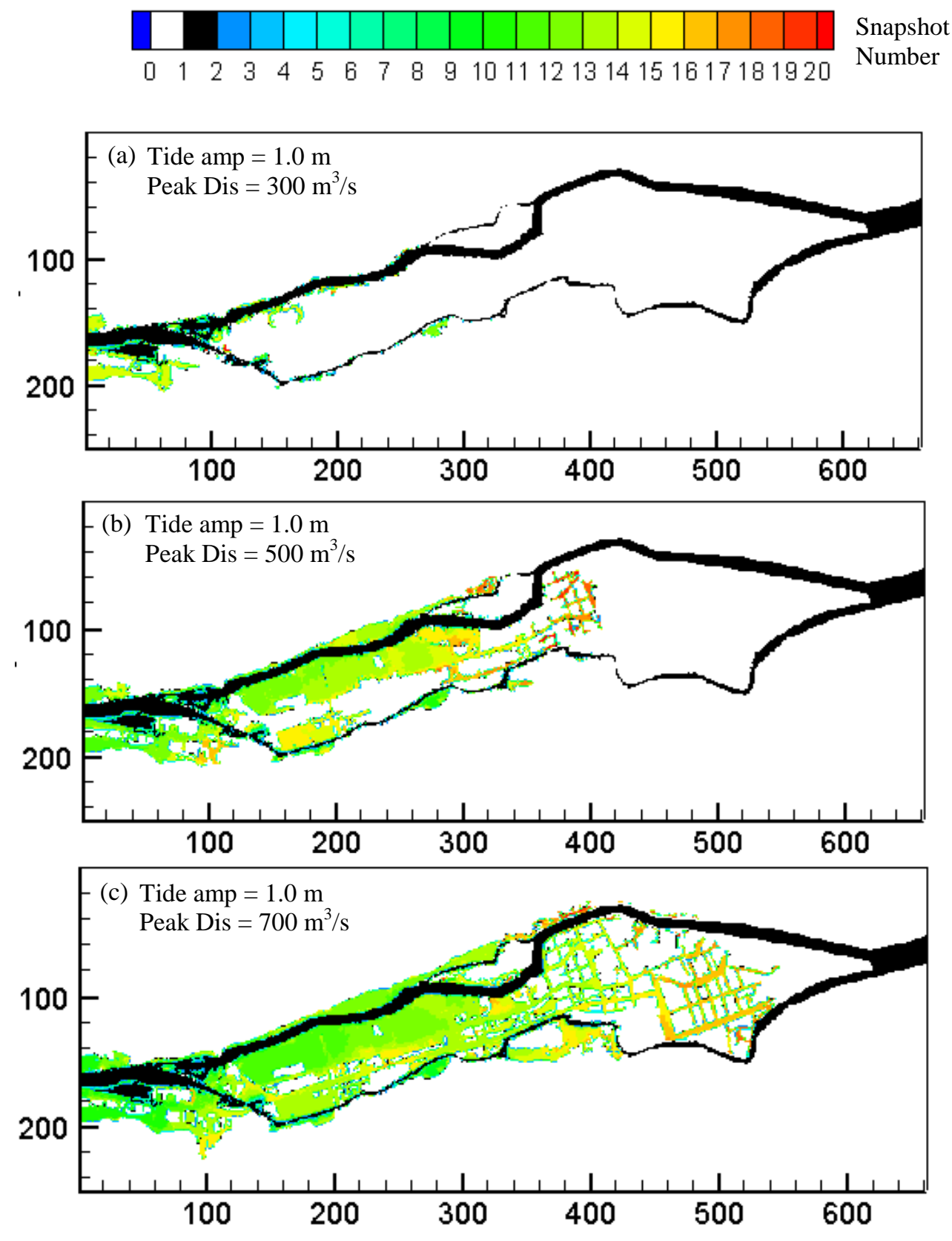

Figure 8: Temporal and spatial evolution of fluvial flood wave through Cork City for different peak discharge scenarios on a neap tide; contours represent the flood water extents at 2-hourly intervals. The river channel is shown in black. The legend represents the snapshot number, i.e. $1=2 \mathrm{hrs}$ and 20 $=40$ hrs. 


\section{Conclusions}

The 2D, depth-averaged, finite difference urban flood model, MSN_Flood, was used to investigate the process of fluvial flooding in Cork city, Ireland. The city is prone to a combination of fluvial and coastal (tide and surge) flooding. The following are the main conclusions from the study:

- Thanks to its nested structure and treatment of nested boundaries, MSN_Flood is capable of accurately predicting complex urban flooding and therefore can be used to draw inferences about flood mechanisms and extents in urban environments under various flood scenarios.

- Peak river flows below $300 \mathrm{~m}^{3} / \mathrm{s}$ (corresponding to 5.7 -year return period event (Olbert et al., 2015)) do not cause extensive flooding, regardless of sea water level state. Rates exceeding peak flows of $500 \mathrm{~m}^{3} / \mathrm{s}$ generate significant flooding of the city centre area.

- There is a strong relationship between river flows and inundated area expressed by a power function. Doubling the flow rate may result in expansion of inundation by up to 10 times. Spring tides may exacerbate the extents of river flooding to the order of 5\%.

- In order to fully understand the flooding mechanisms in Cork City, a more thorough study of the various contributions of river, tide and surge is required, including joint probability analysis of the contributing factors. This is currently in progress and will be published in due course.

\section{Acknowledgements}

The authors would like to acknowledge This material is based upon works supported by Science Foundation Ireland under Grant No. 12/RC/2302 through MaREI, the national centre for Marine and Renewable Energy Ireland. The authors wish to acknowledge the DJEI/DES/SFI/HEA Irish Centre for High-End Computing (ICHEC) for the provision of computational facilities and support.

\section{References}

Comer, J., Olbert, A.I., Nash, S., Hartnett, M. (2017) Development of high-resolution multi-scale modelling system for simulation of coastal-fluvial urban flooding. Natural Hazards and Earth System Sciences 17: 205-224

Fewtrell, T.J., Neal, J.C., Bates, P.D., Harrison, P.J. (2011) Geometric and structural river channel complexity and the prediction of urban inundation. Hydrological Processes 25: 3173-3186.

Hunter, N.M., Bates, P.D., Neel, S., Pender, G., Villanueva, I., et al. (2008) Benchmarking 2D hydraulic models for urban flood simulation. ICE Water Management 161: 13-30.

Mark, O., Weesakul, S., Apirumanekul, C., Aroonnet, S.B., Djordjevic, S. (2004) Potentials and limitations of 1D modelling of urban flooding. Journal of Hydrology 299: 284-299.

Nash, S., Hartnett, M. (2010) Nested circulation modelling of inter-tidal zones: details of nesting approach incorporating moving boundary. Ocean Dynamics 60: 1479-1495.

Nash, S., Hartnett, M. (2014) Development of a nested circulation model: boundary error reduction. Environmental Modelling and Software 53: 65-80.

Olbert, A.I., Comer, J., Nash, S., Hartnett, M. (2015) Mechanisms of flooding in Cork City. Proceedings of the 16th National Hydrology Conference, November $17^{\text {th }}$, Athlone, Ireland. 
Olbert, A.I., Comer, J., Nash, S., Hartnett, M. (2017) High-resolution multi-scale modelling of coastal flooding due to tides, storm surges and rivers inflows. A Cork City example. Coastal Engineering 121: 278-296.

OPW (2003) Report of the Flood policy review group. OPW, Ireland. Accessed online on 7/1/17 at: http://www.opw.ie/media/Report\%20of\%20the\%20Flood\%20Policy\%20Review\%20Group.pdf

Small, C., Nichols, R.J. (2003) A global analysis of human settlement in coastal zones, Journal of Coastal Research 19: 584-599.

Yang, Z., Wang, T., Khangaonkar, T., Breithaupt, S. (2012) Integrated modelling of flood flows and tidal hydrodynamics over coastal floodplains. Environmental Fluid Mechanics 12: 63-80. 